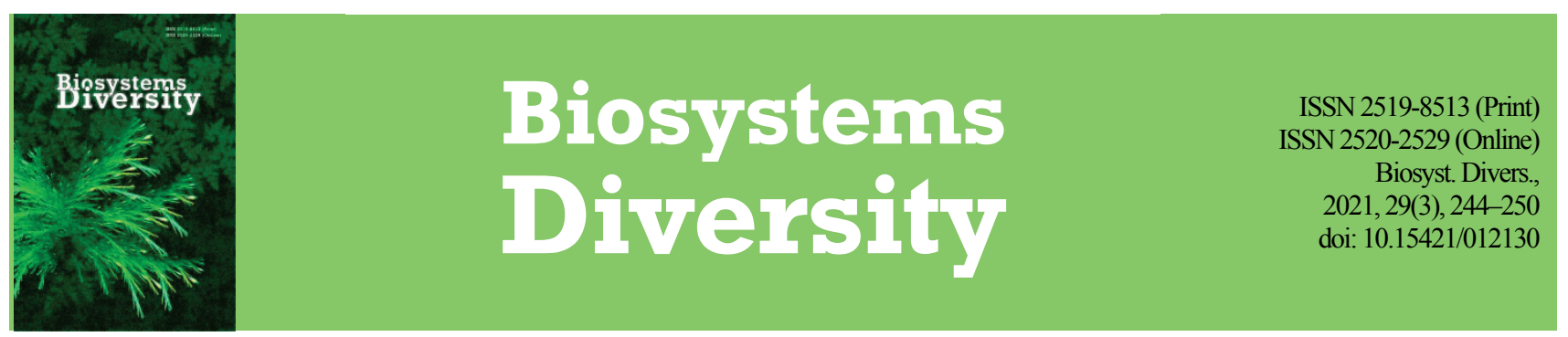

\title{
Features of Trifolium rubens (Leguminosae) ontomorphogenesis in conditions of Ukraine
}

\author{
A. M. Gnatiuk*, M. B. Gaponenko*, A. M. Gaponenko** \\ *M. M. Gryshko National Botanical Garden of National Academy of Science of Ukraine, Kyiv, Ukraine \\ **National University of Life and Environmental Sciences of Ukraine, Kyiv, Ukraine
}

Article info

Received 28.06.2021

Received in revised form 23.072021

Accepted 24.07.2021

M. M. Gryshko National

Botanical Garden of National

Academy of Science of Ukrain

Timiryazevska st., 1 ,

Kyiv, 01014, Ukraine.

Tel.: +38-044-285-41-05.

E-mail:

gnatiukalla@gmail.com

National University of Life and Environmental Sciences

of Ukraine, Heroiv Oborony st.,

15, Kyiv, 03041, Ukraine

Tel.: +38-044-270-27-82.

E-mail:

Gnatiuk, A. M., Gaponenko, M. B., \& Gaponenko, A. M. (2021). Features of Trifolium rubens (Leguminosae) ontomorphogenesis in conditions of Ukraine. Biosystems Diversity, 29(3), 244-250. doi:10.15421/012130

The necessary basis for studying the structure and dynamics of populations is an investigation of ontomophogenetic peculiarities and establishment of ontogenetic stages of individuals. Information about ontomorphogenesis is especially important for protected species of plants. The minimal amount of data on morphology of plants in the different periods of ontogenesis complicates plant identification and evaluation of population state conditions in nature and culture. Trifolium rubens L. is a perennial Central European plant listed in the Red Book of Ukraine as a rare species. The objective of this research is to analyze the peculiarities of ontomorphogenesis of $T$. $r u$ bens, to establish diagnostic signs of age stages and the sequence of their passage for identification of the multivariance of development. The results of the study on T. rubens ontomorphogeny at the M. M. Gryshko National Botanical Garden of the National Academy of Sciences of Ukraine and in the natural population in Zakarpattya are represented in this article. The terms "age stage" and "age period" are used to describe the degree of ontogenetic development of individuals. Diagnostic features of the age periods: latent, pregenerative, generative and senile are established. Detailed morphological descriptions of plants in different stages of ontogenesis are presented. The study shows a multivariate development that reveals different sequences of passing ontogenesis stages by individuals and, accordingly, the rate of their aging and life expectancy. It was found that during the first year of vegetation the plants undergo two periods (latent and pregenerative) and 5 stages of ontogeny (latent, seedlings, juvenile, immature and virginile). The first bloom in plants appears mainly in the second year of vegetation. The research showed the change of the leaf blade shape in ontogeny from simple to compound. There is a difference in the pubescence of leaf parts, and leaf shape indicates that these features are age-old. It was concluded that the aboveground part of the immature, virginile, generative individuals during the flowering period of plants differ from subsenile and senile in shape and number of leaves. In the generative period of ontogeny in dense plantings or in the natural population, it is difficult to reliably determine the boundaries of an individual by the aboveground part. The correlation between vegetative shoots of different type and generative shoots in the individual or group of plants can be used as an indicator to estimate the ontogenetic status of a particular locus or population. Successful growth of T. rubens in culture outside the natural range indicates good prospects for its ex situ protection and the implementation of measures for repatriation and restoration of populations in nature. The data of the research may be used for evaluation of the age structure of $T$. rubens populations.

Keywords: ruddy clover; ontogeny; rare plant; morphology; age stages.

\section{Introduction}

The Leguminosae (=Fabaceae) is the third largest family of flowering plants and one of the important objects of introduction since it plays a leading role in the formation of natural coenoses and agrocenoses (Bondarchuk \& Rakhmetov, 2016). The clover genus, Trifolium L., is one of the largest genera in the family (Ellison et al., 2006). More than 300 species of the genus Trifolium are common in all continents except Australia (Bobrov, 1945; Pavlova, 1989; Kolodziejek, 2018). The vast majority of them are agriculturally important forage species and medicinal plants, very often with root-nodules that harbour nitrogen-fixing bacteria. Representatives of the genus have been actively studied in various aspects due to their useful properties (Abberton, 2007; Kalinkina, 2013; Marek-Kozaczuk et al., 2017; Cruz-González et al., 2017).

The genus Trifolium is represented in the flora of Ukraine by 38 species (Mosyakin \& Fedoronchuk, 1999), but only two are listed in the Red Book of Ukraine (2009). The Trifolium rubens L. (ruddy clover) is a rare plant and needs special attention and study to ensure its conservation. The plant rarely occurs in the right-bank part of Ukraine. It is registered from Vinnytsia, Zakarpattia, Ivano-Frankivsk, Lviv, Rivne, Ternopil, Khmelnytsky, and Chernivtsi regions. Most locations are known from Zakarpattia and Lviv regions (Gnatiuk et al., 2021). The natural habitats of the species are mainly in the area of deciduous forests with moderate and sufficient moisture. The optimal amount of precipitation for the distribution of the species is $600-700 \mathrm{~mm}$ per year (from $800 \mathrm{~mm}$ in Transcarpathia to $500 \mathrm{~mm}$ in Vinnytsia region). Decreased precipitation is a limiting factor for the spread of the species. Only one location is known in an area with insufficient moisture (forest-steppe). The total duration of precipitation per year in the regions of the distribution of the species is not less than 70 hours, during the growing season (April-October) the average rainfall in this area is more than $425 \mathrm{~mm}$, but the total evaporation in summer does not exceed $280 \mathrm{~mm}$ (Lipinsky et al., 2003). Trifolium rubens occurs in meadow-steppe and meadow areas, on hillsides, and also participates in mesoxerophilous secondary (semi-natural) shrub communities in anthropogenically transformed areas. Often such populations are situated along pathways, on forest edges and fallow lands, and associated with communities of the Trifolio-Geranietea sanguinei class. This species is characterized by stenotope ecocenotic amplitude and is sensitive to undue influence of anthropogenic factors and is poorly restored (Didukh, 2009; Gnatiuk et al., 2021). The number of localities and populations has declined (Didukh, 2009). The plant is almost entirely unprotected outside the natural habitats (ex situ) (Gaponenko et al., 2011).

Trifolium rubens is a herbaceous perennial with a taproot. Stems (shoots) are numerous, mostly simple, sometimes branched, rigid, glabrous, erect, or ascending, grow up to $20-80(90) \mathrm{cm}$ tall, often reddish. The leaves are alternate, trifoliate, in outline ovate, each leaflet oblong, 
elliptic or lanceolate, $4-8 \mathrm{~cm}$ long and $1.0-1.5 \mathrm{~cm}$ wide, mostly naked, serrate, on the underside with a thick mesh of veins. The stipules are well developed, green, not hairy, fused with the petiole in their lower part for most of its length, their bases form a ring round the stem. The stipules are lanceolate in the free part, often exceeding the petiole. Inflorescence is a dense, racemose head, mostly 1-2 at the ends of stems, oblong, ovate, or cylindrical form, $4.0-10.0 \mathrm{~cm}$ long and $2.0-3.5 \mathrm{~cm}$ wide. The peduncle is 2-3 times shorter than the head. The corolla is reddish, $1.3-1.6 \mathrm{~mm}$ long, with a long tube. The calyx of each small flower is smooth, $4-6 \mathrm{~mm}$ long with 20 not very distinct veins, naked, with a thick ring of hairs in the throat. The teeth of the calyx have long white hairs; the lower of them are much larger than the tube. The banner is ovate and sharp, the wings are of the practically same length as the banner, but of a paler colour, the keel is shorter and of a darker purple (Bobrov, 1945; Visjulina, 1964; Didukh, 2009). Insects, mainly bumblebees, pollinate the flowers. Like in other polycarpic perennial plants, the shoot system is represented by elongated monocyclic monocarpic shoots. Shoots develop from the buds formed on perennial parts of the plant's shoot (caudex head or rhizome) (Kalinkina, 2017).

Trifolium rubens has been studied since 2005 at the plots of the Cultural Flora Department of M. M. Gryshko National Botanical Garden of NAS of Ukraine. V. G. Mykolaychuk published data on the morphology of inflorescences, leaves, features of flowering, and fruiting of T. rubens plants in different years of vegetation in ex situ conditions. The influence of plant age on morphological features of inflorescences and seed productivity has been revealed (Mikolaychuk, 2012; Mikolaychuk, 2015).

Trifolium rubens is a promising object for ex situ protection and cultivation in industrial culture in Ukraine as a multifunctional plant: decorative, fodder, medicinal, phytomeliorational, melliferous, soil-improving. But it is very important to monitor the current state of populations and their dynamic in the natural habitats. Description and analysis of the structure and dynamics of plant populations require classification of individuals, especially if the species are long-lived and show overlapping generations. Plants can be categorized by age or developmental stage, used separately or in combination (Diets \& Ullman, 1998; Hiebert-Giesbrecht et al., 2018). Through increased understanding of the life cycles of plants, it is possible to predict the behaviour of populations in particular habitats, to identify crucial stages of their ontogeny that contribute to population growth, and to target those stages as part of demographic monitoring. This approach is also relevant to conservation managers and decisionmakers due to its relative simplicity and fairly minimal time and resource requirements (Kricsfalusy, 2016).

However, we did not find in the literature information on categories by age or developmental stage, ontomorphogenesis of $T$. rubens and detailed descriptions of the plant in different age periods, which makes it impossible to adequately assess populations of plants. This study aimed to identify and describe the ontogenetic stages, investigate the ontogenetic peculiarities of plants, establish the boundaries of ontogenetic stages, and their multivariate passing by individuals. The data will be used to evaluate the age (ontogenetic) structure of the population of $T$. rubens in nature.

\section{Materials and methods}

The growth and development of $T$. rubens plants were studied in situ (in Zakarpattya) and ex situ (in M. M. Gryshko National Botanical Garden of NAS of Ukraine (hereinafter-NBG)) conditions.

Zakarpattya (Zakarpatska Oblast) is a region in the west part of Ukraine. We studied T. rubens in natural populations in the foothills of the Volcanic Carpathians in Zakarpattya: within the low mountain range of the Berehovo volcanic hills in June (flowering period) and in August (fruiting period). The study was carried out in 2016-2020. The floristic compositions of the plant communities and the structure of these populations are shown in the previous article (Gnatiuk et al., 2021).

Trifolium rubens was studied in NBG during the period of vegetation. NBG is located in the south-eastern part of Kyiv city $(50.4149 \mathrm{~N}$, $30.5628 \mathrm{E}$ ), which is outside the natural range of T. rubens. The site is within the Right-Bank Forest Steppe of Ukraine, a temperate climate zone. Observations were conducted for 6 years (2014-2020). The studies were carried out at the "Rare species of Ukrainian Flora" plot of the Natu- ral Flora Department. The soil in the study area is dark grey, podzolic, sandy, with a humus content of $2.6 \%, \mathrm{pH} 6.5$. The subject was T. rubens individuals of seed origin. Seeds were collected from individuals available in the collection of the Natural Flora Department of NBG from the natural populations of Ukraine and obtained by exchange from other institutions, in particular from Poland, Germany, Switzerland and France.

Ontogenesis and morphogenesis have been studied by conventional methods (Rabotnov, 1950; Smimova et al., 1976; Semenova, 1989). Plants were dug out, stained, and photographed at various stages of development. Since T. rubens is protected, the plants were replanted into the previous growth site after the research. Each age stage was described using at least 10 plants and the literature data (reference to add). The sizes of individuals in the text are given as an interval from the smallest to the largest values of the indicator (in brackets values are given that were rare). The plant morphology was described in terms accepted in current ontogenetic studies (Bondarchuk \& Rakhmetov, 2016; Kalinkina, 2017).

To describe the stages of plant development, as in other similar articles, we use the terms "age stage" and "age period" (Gnatiuk \& Grytsenko, 2019; Gnatiuk, 2020). The aging stage of individuals was identified according to a set of structural characters of their above-ground and underground parts. The main criteria for the identification of age periods and stages are the following. Latent period (se) - dormant seeds. Pregenerative period (virginile or virginal period): seedlings $(\mathrm{p})$ - have mixed nutrition (exist due to the substances of the seed and its assimilation), available embryonic structures: cotyledons, primary root, and shoot. Juvenile stage (j) is characterized by the simplicity of organization, the unsteadiness of signs and properties, which are not inherent in adult plants: the presence of another leaf form, another type of growth and branching, the retention of some embryonic structures (root, shoots, cotyledons). Immature stage (im) - properties and characteristics of plants are transitional from juvenile to adults: leaves and the root system are of transitional (semi-adult) type, individual elements of the primary shoots are preserved. Virginile stage (v) - characterized by the appearance of the main features typical for the adult individuals. Generative organs are not yet present. Generative period: young generative $\left(g_{1}\right)$ - individuals have generative organs. Growth processes outweigh the dying. Mature generative $\left(\mathrm{g}_{2}\right)-\mathrm{a}$ characteristic balance of growth and dying processes, maximum annual biomass growth, maximum seed productivity. Old generative $\left(\mathrm{g}_{3}\right)$ shows an inherent predominance of dying processes over recovery processes. Senile period: sub-senile stage (ss) - absence or insufficient fruiting (abortive flowers or inflorescences are possible). The predominance of dying processes over recovery. Senile stage (s) - accumulation of dead (stopped growth) parts of a plant. Simplifying life form (reducing the number and size of leaves, shoots, etc.). Multivariate development of individual groups of plants is shown schematically using the following symbols: $\rightarrow-$ moving to the next stage of development; $\mid$ - completion of vegetation; $\ddagger-$ stay longer than one year.

Quantitative indicators were processed by the methods of variation statistics. The main descriptors used: mean and standard deviation, minimum and maximum value.

\section{Results}

Latent period. Seed (se). The vegetation period of T. rubens in Kyiv conditions lasts about six months: it begins in the last decade of AprilMay and ends in the first decade of October. Ontogeny of a plant is described from the latent period and the first age stage is the seed (se). The seeds ripen in September-October, formed in a scarious single-seeded bean, which is hidden at that time in the dry flower's calyx (Fig. 1). T. rubens seeds are brownish-yellow with a greenish tinge of colour gamut (the intensity of colour depends on the degree of maturation of the seeds), sometimes with darker spots on the surface, averaging $1.8 \pm 0.1 \mathrm{~mm}$ in length and $1.5 \pm 0.2 \mathrm{~mm}$ in width, rounded kidney-shaped, seed scar is in the recess, round, almost white, the surface of the seed is smooth matte, raphe is inconspicuous.

Pregenerative (virginile) period. Seedlings (p). Germination is epigeal, hypocotylar (Fig. 2). With spring sowing, the seeds sprout in 715 days during the same year. Development begins with the appearance of the primary root and its gradual deepening. 
In laboratory conditions at temperatures of $18-20^{\circ} \mathrm{C}$ a root appears mainly on days $7-10$, some seeds germinate after 3 days. The timing of seed germination in laboratory conditions depended on the degree of ripening: brown seeds germinated faster (on days 7-15), and olive and yellow - slower (on days 25-30). The seedlings have rounded or oval cotyledons $3-5 \mathrm{~mm}$ long and 2-3 mm wide with short petioles and a prominent main root. The root system is $2-5 \mathrm{~cm}$ long.

Juvenile stage (j). The transition to the juvenile stage comes on the 17-th to 20-th day after sowing - the first true leaf begins to form. This leaf is simple with the petiole (5-17 mm long) with a leaf blade almost rounded or slightly obcordate (4-8 $\mathrm{mm}$ long and 3-7 $\mathrm{mm}$ long). The petiole and leaf blade at the edge and below the vein on the abaxial side of the leaf surface are pubescent with relatively long hairs (trichomes). Some individuals form two such leaves. Cotyledons increase to 5-7 $\mathrm{mm}$ in length. and $3-5 \mathrm{~mm}$ wide, their petioles extend up to $2-5 \mathrm{~mm}$ in length.

Immature stage $(\mathrm{im})$. The transition of plants to the immature stage occurs on the 20-25-th (30) days after sowing of seeds and is characterized by the appearance of juvenile-type compound leaves (Fig. 3, 4). In the laboratory conditions, the appearance of the first compound leaf occurred 5-7 days after the emergence of the sprouts. The immature plants have 2-5 compound trifoliate leaves with long petioles and a small stipules. Leaves grow in turn at intervals of 5-6 days. Leaflets are oval or obcordate with a cuneiform or rounded base and a depressed emarginate apex with a clear central vein and very short petiolules. The first compound leaf has three leaflets $4-6 \mathrm{~mm}$ in length and $3-5 \mathrm{~mm}$ wide. On the following leaves, they are larger (up to $1.5 \mathrm{~cm}$ long and $0,8 \mathrm{~cm}$ wide). 3-4 trifoliate leaves appear in a plant, cotyledonous, and behind them the first true leaf gradually dries. The stipules, petioles, and leaves are pubescent at the edge and below the veins. The taproot system is enlarged and branched, the lateral roots thicken. Some individuals have some root nodules that contain nitrogen-fixing bacteria. At the base of the vegetative shoot 1-2 renewal buds are formed. In individuals, one of these buds can sprout in its year of appearance.

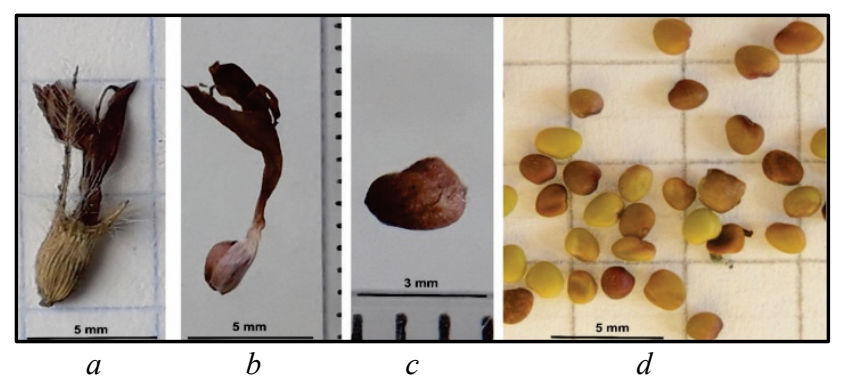

Fig. 1. Fruits and seed of Trifolium rubens L: $a$-calyx and dried flower; $b, c$ - pod; $d$ - seed

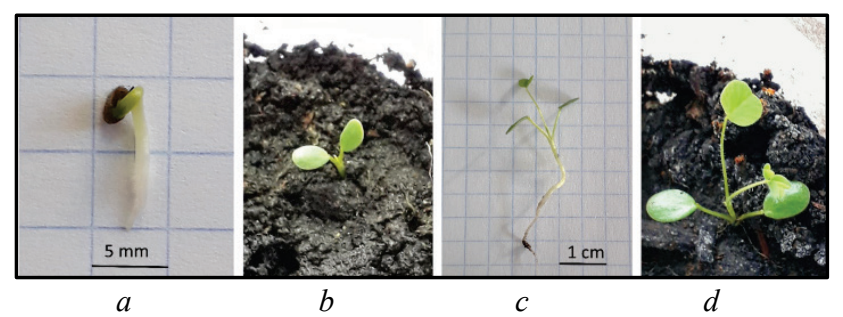

Fig. 2. Germination of Trifolium rubens L. seed (by days): $a-7$ day; $b-11$ day, $c-16$ day, $d-26$ day

Virginile stage (v). Young virginile $\left(v_{1}\right)$. The plants in the virginile stage are characterized by the absence of the cotyledons and the first true simple leaves. Virginile plants have only compound leaves of the juvenile type. By the end of the first year of vegetation individuals are $15-25 \mathrm{~cm}$ tall, mainly with 10-11 trifoliate leaves on the orthotropic shoot. In the lower (basal) part of the shoot 2-3 renewal buds form, the root system is enlarged, the lateral roots are clearly visible.

Thus, during the first year of vegetation, the main shoot and the plant as a whole generally undergo two periods (latent and pregenerative) and five stages of ontogeny (latent, seedlings, juvenile, immature and virginile). All aboveground organs of annual plants (shoots, sepals, stipules on the edge, leaf blade on the edge, and by veins) are different from older ones and plants in the generative and postgenerative conditions because they have hairy trichomes $0.8-0.9$ (to 1.5 ) $\mathrm{mm}$.

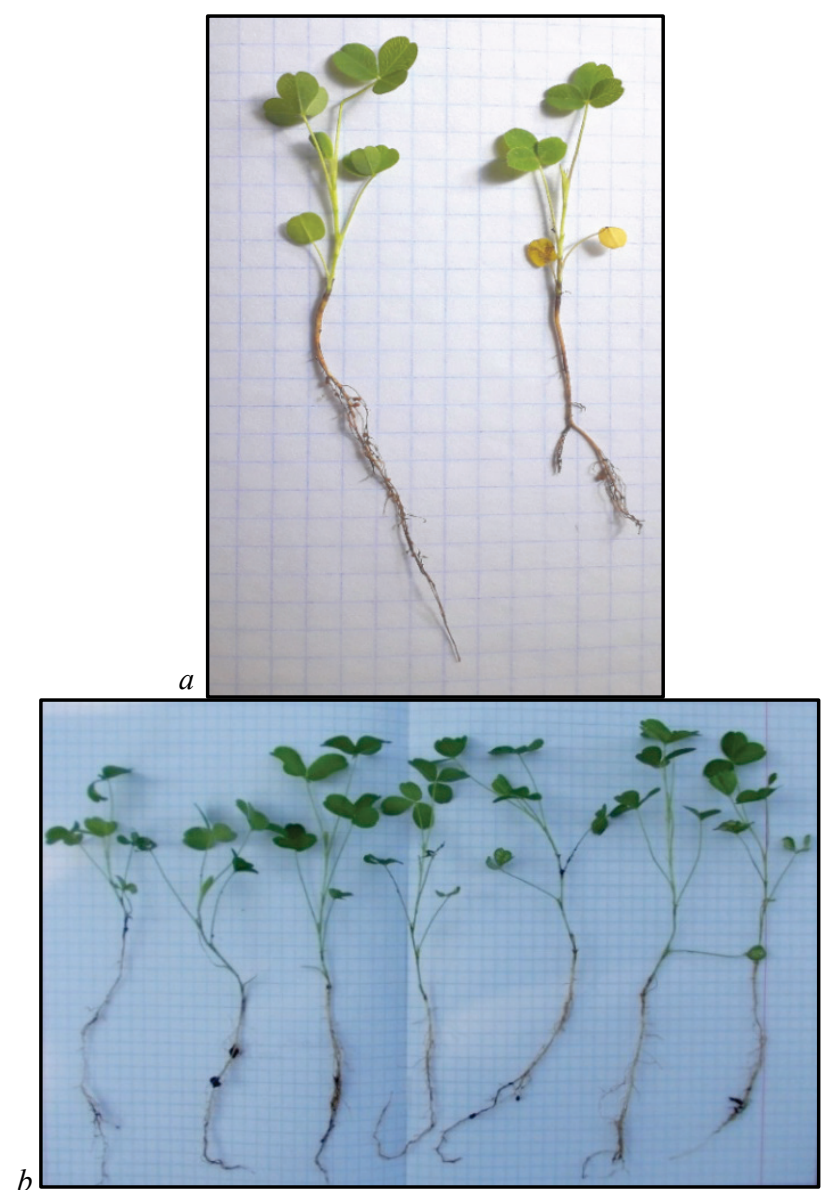

Fig. 3. One-year plants of Trifolium rubens L:: $a$-plants with simple leaves, $b$ - plants with compound leaves only (scale cell $5 \times 5 \mathrm{~mm}$ )

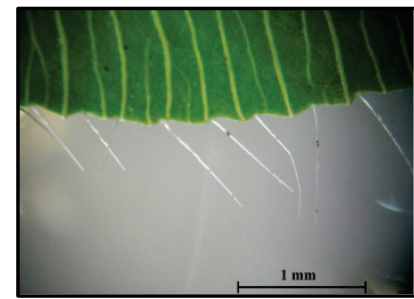

$a$

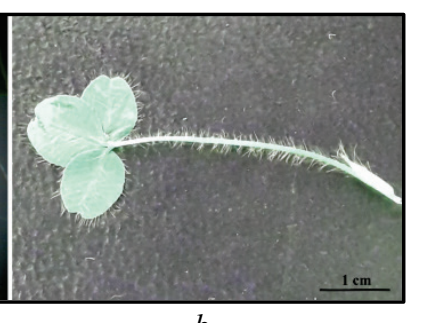

$b$
Fig. 4. Juvenile compound leaf of Trifolium rubens L: $a$-the edge of the leaf with trichomes, $b$-the general view

Older virgile $\left(v_{2}\right)$. Not all individuals come to the generative stage in the second year. Two-year-old plants may still not be flowering. Such individuals may develop one to three shoots of the virginile type (Fig. 5). Virginile plants older than 1 year have 6-12 leaves on the shoot, with a predominance of definitive leaves. Such trifoliate leaves are glabrous with oblong or slightly lanceolate leaflets with obtuse or emarginate apices and a serrate leaf margin (Fig. 6). Only 2-3 upper leaves can be juvenile type: leaves shorter and rounded, with trichomes on edges or the middle vein. The root system has pronounced lateral roots.

Generative period $(g$ ) can last more than 10 years. In winter in Kyiv the above-ground part of the annual shoots freezes to the level of snow cover. The spring regrowth of plants in culture begins with the sprouting of the lateral buds on the above-ground shoots, located in the axils of the previous year's leaves and (or) the underground buds. T. rubens plants are winter-hardy hemicryptophyte or chamephite in the conditions of Kyiv. Plants bloom annually, forming fruits and seeds, and their annual cycle of development is consistent with seasonal climatic fluctuations. Until JuneJuly vegetative and generative shoots are formed (Fig. 5, 8). 
Generative plants from renewal buds form several shoots, which differ in the degree of development. The appearance of the generative shoot is a characteristic feature of the generative stage of ontogenesis. Under the generative shoot, we take a constructive unit that develops from the renewal bud and includes the stem, leaves, buds, and flowers or fruits. Generative shoots of plants are 30-65 cm high, mostly with 8 (rarely 6 or 7) green leaves. The leaves of the generative shoots in T. rubens are mostly definitive: trifoliate, glabrous, only the upper leaves on the veins below have single long trichomes. Compound leaves are $5.7-14.0 \mathrm{~cm}$ long with long stipules $3.2-7.5 \mathrm{~cm}$ long, leaflets $3.0-6.6 \mathrm{~cm}$ long and $0.6-0.9 \mathrm{~cm}$ wide with short petiolules $0.1-2.0 \mathrm{~cm}$ long. The leaflets of the upper leaves of the vegetative shoots are similar to juvenile, smaller, and have a more rounded shape too. Flowering occurs in June-July, fruiting in JulyAugust. Quite often, during the maturation of the seeds, plants grow lateral buds. Juvenile leaves are distinguished by these new shoots of the second order. On some of them by the end of September-October inflorescences are formed and the flowering of plants is observed again. Inflorescences are elongated $2.8-6.0 \mathrm{~cm}$ long and $1.7-2.5 \mathrm{~cm}$ in diameter, lateral. The first inflorescences to form are 1-2 at the top of the shoots. Later, the inflorescences begin to bloom on the lateral shoots of the second order of branching.

Vegetative shoots of generative plants can be divided into virginile, subsenile, and senile types. Shoots of virginile type are similar to generative ones but do not have flowers or fruits. Shoots of subsenile type also don't have flowers/fruits but they are lower and have fewer leaves. Seniletype shoots are defectively developed with 2-4 leaves on the shoot stem. 1 to 6 inflorescences may form on one generative shoot by the end of the growing season (Fig. 7). In culture, generative shoots with two inflorescences are most often formed. On average, three-year-old generative plants in the years of observation formed $12.1 \pm 1.8$ shoots/plant and 18.0 \pm 3.9 inflorescences/plant (Table 1).

Young generative $\left(g_{l}\right)$ - in individuals which first enter into the generative stage, the taproot system is with a pronounced main root and mainly with 1-3 renewal buds, forming the same number of above-ground shoots. In older individuals, the root system enlarged with several thickened lateral roots, which are almost indistinguishable from the main root. Plants form 1-4 shoots in spring. One or two of them are generative with one or two inflorescences. The first-time flowering plants often have transitional leaves from juvenile to adult, they may be slightly rounder in shape and partially with pubescence.

Mature generative $\left(g_{2}\right)$ - individuals older than three years. Vegetation begins with the sprouting of new shoots from the renewal buds. Individuals form 4-7 or more generative shoots, sometimes 1-2 of them can be vegetative. As a result of their branching, 9-12 lateral shoots are formed. Lateral shoots can form inflorescences. On each generative shoot, 2 or 3 (rarely 1 or 4-6) lateral with inflorescences are formed. Regardless of age and number of shoots, in generative plants, generative shoots prevail over vegetative ones (Table 1). The root system complicates, formed by the main, numerous thickened lateral and additional roots that develop at the base of the buds.

Old generative $\left(g_{3}\right)$. Aging of individuals is expressed in the gradual loss of ability to bloom profusely and bear fruit. Individuals form mainly vegetative shoots. The number of adventitious roots increases, the main root is not expressed, and there is an opportunity for artificial vegetative propagation.
Senile period. Aging occurs both physiologically and due to deteriorating growth conditions: lack of moisture, lighting, local depletion of the soil by the plant itself, allelopathic influence of its remains, which causes depression of plant growth, competition from other plant species, anthropogenic and zoogenic impact. Plants gradually lose the ability to reproduce, there is growth inhibition and death of individual plant organs.

Sub-senile stage (ss). There may be one or more aboveground shoots, they are smaller than those of generative individuals, $10-25 \mathrm{~cm}$ tall. Plants develop vegetative, subsenile, and senile types of shoots only, with 4 7 trifoliate leaves. The leaves are definitive. The root system is unilateral often, which results from their destruction, with one or more thickened roots, branched by additional adventitious roots and underground ascending or vertical short rhizomes formed by the base of the shoots (Fig. 9).

The senile stage $(s)$ is the final stage of the degradation of the individual. There is no flowering, the aboveground shoots of senile type are 10 $15 \mathrm{~cm}$ in height with 2-3 leaves, leaves $0.9-1.5$ in length, and $0.7-0.8 \mathrm{~cm}$ in width. Shoots are delimited by other species of plants. Plants develop subsenile and senile types of shoots.

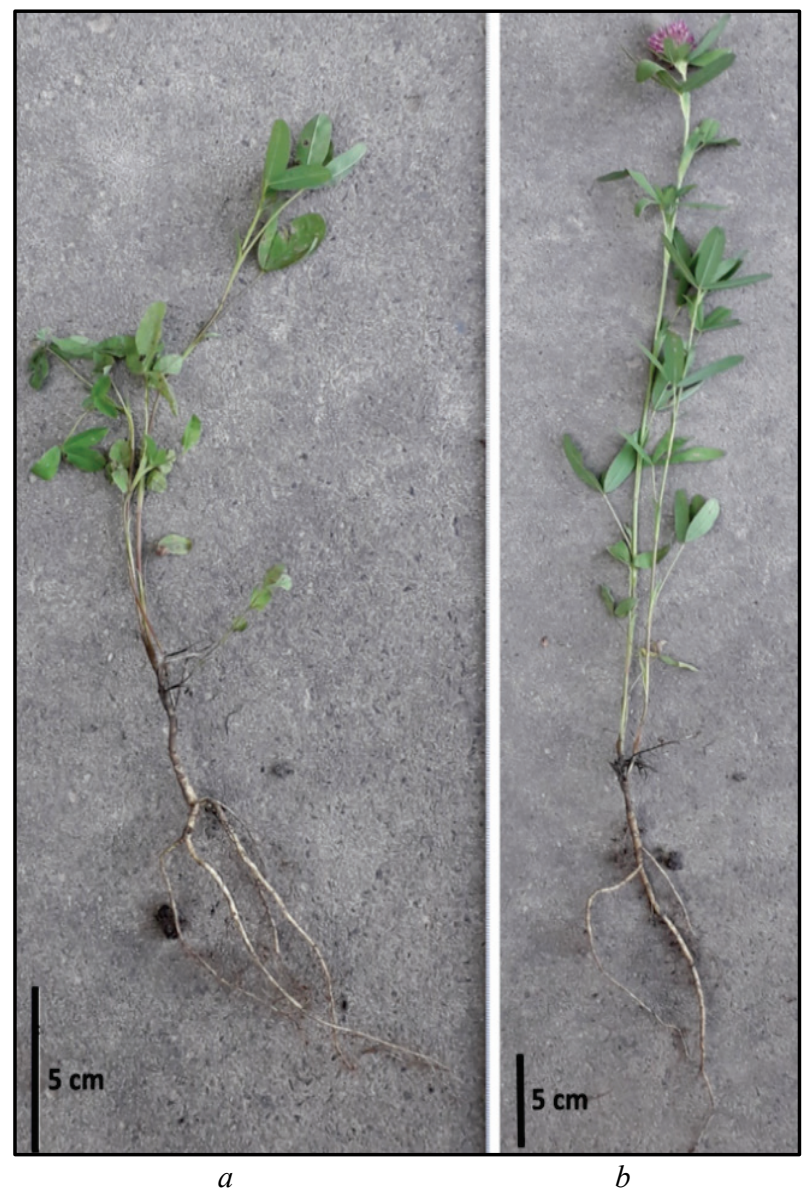

Fig. 5. Two-year-old plants Trifolium rubens L.: $a$-virginile; $b$ - generative plant

Table 1

Characteristics of shoots in 3-year-old generative plants in culture

\begin{tabular}{|c|c|c|c|c|c|c|c|c|c|c|c|c|}
\hline \multirow[b]{2}{*}{ Indicator } & \multicolumn{4}{|c|}{ Number of different shoots/plant } & \multicolumn{6}{|c|}{ Distribution of generative shoots by the inflorescences number } & \multirow{2}{*}{$\begin{array}{l}\text { Number of } \\
\text { shoots/plant }\end{array}$} & \multirow{2}{*}{$\begin{array}{c}\text { Number of } \\
\text { inflorescences } \\
\text { / plant }\end{array}$} \\
\hline & generative & virginile & subsenile & senile & 1 & 2 & 3 & 4 & 5 & 6 & & \\
\hline $\mathrm{N}$ & 106 & 22 & 5 & 0 & 32 & 64 & 5 & 3 & 1 & 1 & 133 & 198 \\
\hline Min & 1 & 1 & 0 & 0 & 0 & 1 & 0 & 0 & 0 & 0 & 4 & 2 \\
\hline Max & 22 & 5 & 2 & 0 & 10 & 11 & 3 & 3 & 1 & 1 & 22 & 38 \\
\hline $\mathrm{X}$ & $9.6 \pm 2.0$ & $2.0 \pm 0.5$ & $0.5 \pm 0.2$ & 0.0 & $2.9 \pm 1.0$ & $5.8 \pm 1.1$ & $0.5 \pm 0.3$ & $0.3 \pm 0.1$ & $0.1 \pm 0.1$ & $0.1 \pm 0.1$ & $12.1 \pm 1.8$ & $18.0 \pm 3.9$ \\
\hline SD & 6.5 & 1.6 & 0.7 & 0.0 & 3.1 & 3.5 & 0.9 & 0.4 & 0.3 & 0.3 & 5.8 & 12.2 \\
\hline Shoots, $\%$ & 79.7 & 16.5 & 3.8 & 0.0 & 30.2 & 60.4 & 4.7 & 2.8 & 0.9 & 0.9 & 100.0 & - \\
\hline Inflorescens, \% & 100.0 & - & - & - & 16.2 & 64.6 & 7.6 & 6.1 & 3.0 & 3.0 & - & 100.0 \\
\hline
\end{tabular}

Notes: $\mathrm{N}$-number of units taken into account, min - minimum value; $\max$-maximum value; $\mathrm{X}$ - arithmetical mean and standard error; $\mathrm{SD}$-standard deviation. 


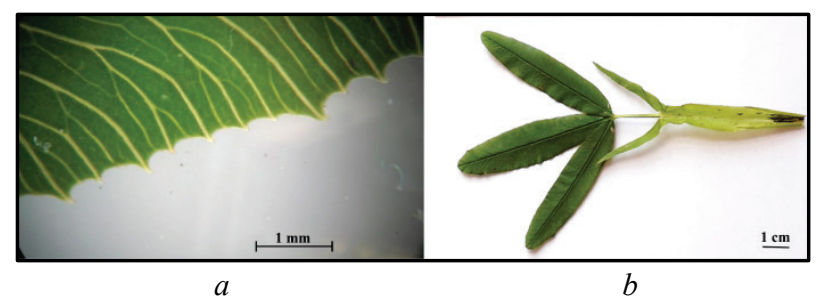

Fig. 6. Definitive leaf of Trifolium rubens L. generative plant: $a$-the edge of the leaf, $b$-the general view

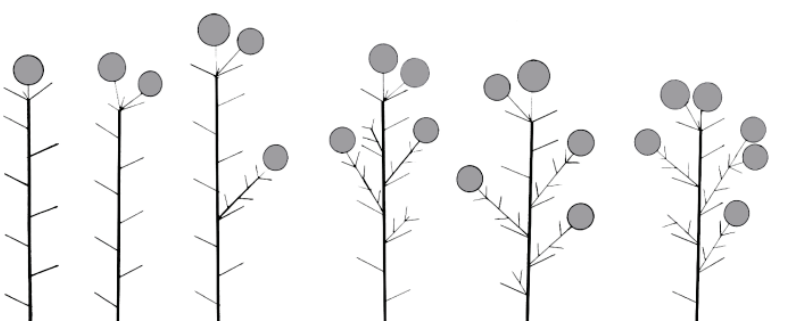

Fig. 7. Sheme of generative shoots variability: I-stem; - - leaves, $\bigcirc$-inflorescence

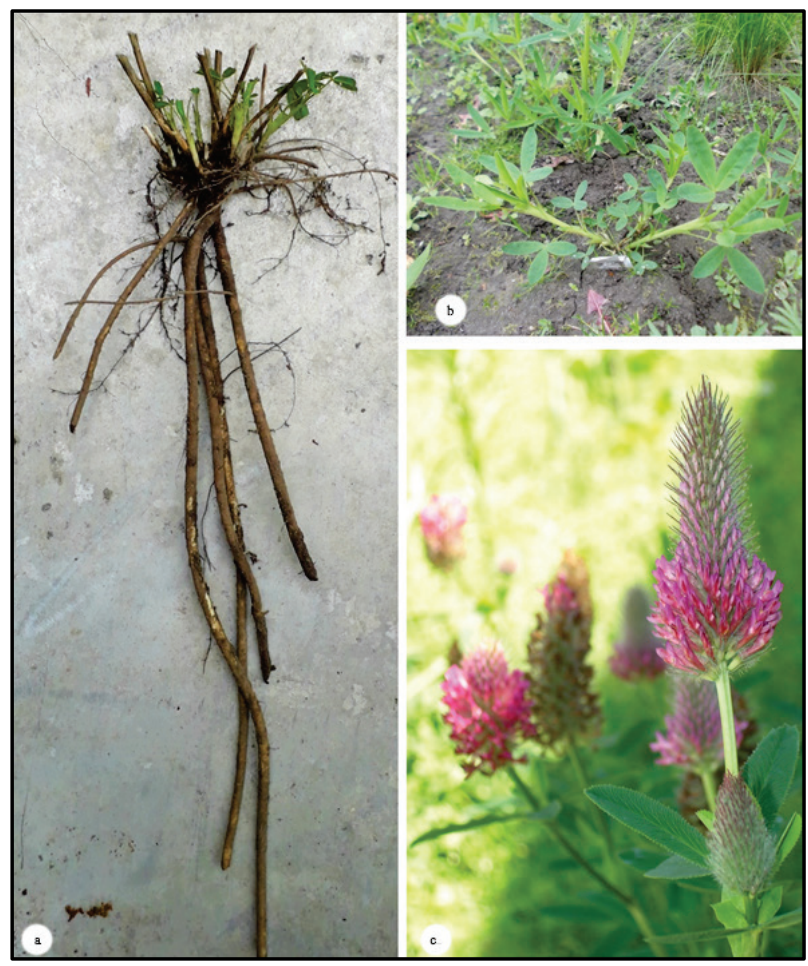

Fig. 8. Generative plants of Trifolium rubens L.:

$a, b$-in spring; $c$-inflorescence in the blooming season

\section{Discussion}

The clover of the Trifolium section is characterized by rounded-ovate seeds with a root from $1 / 2$ or $3 / 4$ of the cotyledon length (Dudik, 1979). The clover's seeds have a strong seed coat, under which there is a weakly expressed endosperm in the form of a thin shell. When the seeds are wetted, the cells rapidly absorb moisture, swell, and increase in size. As a result, the endosperm forms a mucous membrane around the seed germ. The embryo is axial, curved, well-differentiated, has cotyledons, embryonic buds and germinal roots. Mikhailova (1998) notes that scarification of clover seeds increases germination energy and sprouting. Studies by Kołodziejek (2018) have shown that in T. rubens seeds combinational dormancy and scarification should be combined with stratification for best germination. Our research shows that a significant percentage of seeds (60-70\%) are able to sprout without additional measures, a similar result (73\%) was also obtained by Yanenko \& Litvinova (2013) in their research. The size of the seeds is quite consistent with the data of other re- searchers (Zoric et al., 2010). The pregenerative period is not long and lasts mostly 5-6 months of vegetation. Plants that failed to form flowers often become sub-senile and senile, passing the generative period. The plants are in the virginile stage for 1-3 years. The senile period is not well expressed but may last several years. Delayed development of generative plants for more than 1 year indicates that the conditions of plant cultivation are not met and will lead to the formation of sub-senile and senile individuals with their subsequent death. The longest period of $T$. rubens ontogeny is generative. Well-developed 5-10 year old plants form 20-60 (70) shoots, most of which are generative. The development of generative plants occurs mainly in the second year of vegetation. Mykolaychuk (2015) notes that in her experiments only $3.7 \%$ of plants bloomed in the first year. We did not observe one-year flowering plants. Probably, the duration of the pregenerative period of ontogenesis also depends on the local conditions of plant growth.

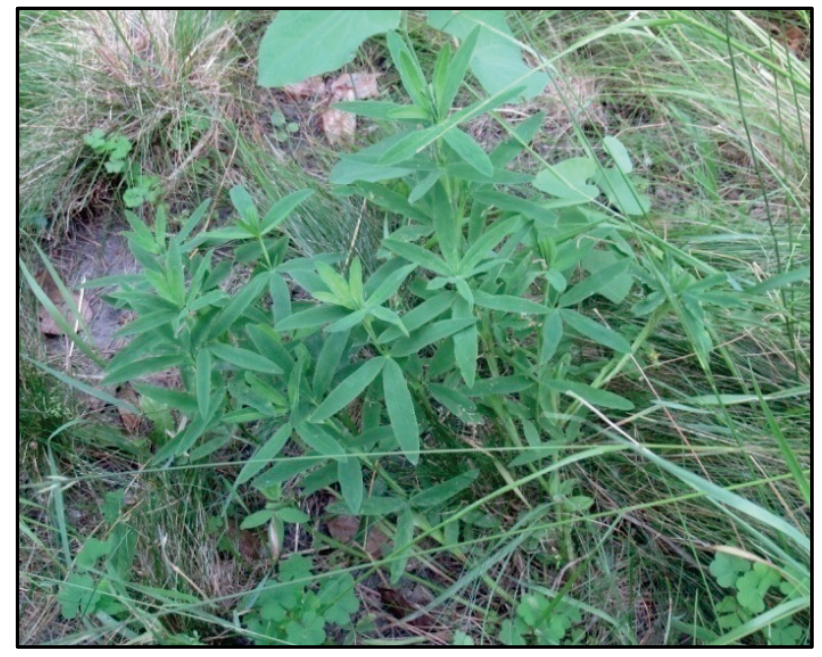

Fig. 9. Subsenile plant of Trifolium rubens L. in the blooming season

Thus the passage of ontogenetic stages by individuals can occur in the following sequence (Fig. 10):

1) $\mathrm{p} \rightarrow \mathrm{j} \rightarrow \mathrm{im} \rightarrow \mathrm{v}_{1}\left|\rightarrow \mathrm{v}_{2}\right| \rightarrow \mathrm{g}_{1}\left|\rightarrow \mathrm{g}_{2} \ddagger\right| \rightarrow \mathrm{g}_{3} \ddagger \mid \rightarrow \mathrm{ss} \ddagger \rightarrow \mathrm{s}$

2) $\mathrm{p} \rightarrow \mathrm{j} \rightarrow \mathrm{im} \rightarrow \mathrm{v}_{1} \rightarrow \mathrm{g}_{1}\left|\rightarrow \mathrm{g}_{2} \ddagger\right| \rightarrow \mathrm{g}_{3} \ddagger|\rightarrow \mathrm{ss}:| \rightarrow \mathrm{s}$;

3) $\mathrm{p} \rightarrow \mathrm{j} \rightarrow \mathrm{im} \rightarrow \mathrm{v}_{1} \rightarrow \mathrm{v}_{2}+\left|\rightarrow \mathrm{ss}^{*}\right| \rightarrow \mathrm{s}_{*}^{+}$

4) $\mathrm{p} \rightarrow \mathrm{j} \rightarrow \mathrm{im} \rightarrow \mathrm{v}_{1} \rightarrow \mathrm{g}_{1}\left|\rightarrow \mathrm{g}_{2} \ddagger\right| \rightarrow \mathrm{g}_{3} \hbar|\rightarrow \mathrm{ss} \hbar| \rightarrow \mathrm{s} \hbar$.

Our studies have shown that in $T$. rubens plants, at the start of the development there are significant differences between the virginile period and later ones. This difference is particularly noticeable in the form of leaves and the degree of pubescence of their parts, which change in ontogeny. Mykolaychuk (2012) also notes that the index of leaf shape changes in T. rubens plants on the generative shoot: the highest indicator is characteristic of the second-tier leaves, at the upper part of the shoot this indicator decreases, that is, the upper-tier leaves have a more rounded shape. This pattern is preserved for all leaflets of a compound leaf (Mikolaychuk, 2012). The change of leaf blade shape in T. rubens in ontogeny from simple to compound trifoliate and the difference in the pubescence of leaf fragments and leaf shape indicates that these features are age-related. Enlargement of the leaf, elongation of the leaf blade in the leaflets, and loss of pubescence of organs expresses a greater degree of their maturity. Therefore, the maturity of individuals should be evaluated by the leaves of the main shoot on the middle formation, since the lateral shoots and leaves of the upper formation are physiologically younger.

Trifolium rubens is a herbaceous polycarpic tap-root plant with a complex system of annual monocarpic shoots. The type of growth of the main shoot is monopodial. Monocarpic shoots of T. rubens, like in other species of the genus, are formed from renewal buds, which are laid on perennial parts of the shoot (caudex or rhizome) and consist of 2-3 shortened and a series of elongated internodes with leaves of different stages of development. Lower leaves - cataphylls, membranous, undeveloped. Renewal buds are laid in the axils of these leaves (Kalinkina, 2016). The monocarpic shoot is mostly not branched. The growth bud of the apical meristem functions as a vegetative, that is, it forms shoot metameres, and the floral meristems are embedded in the leaf axils. In the 
conditions of culture lateral shoots are quite often formed and during an annual cycle of development repeated flowering of plants is observed.

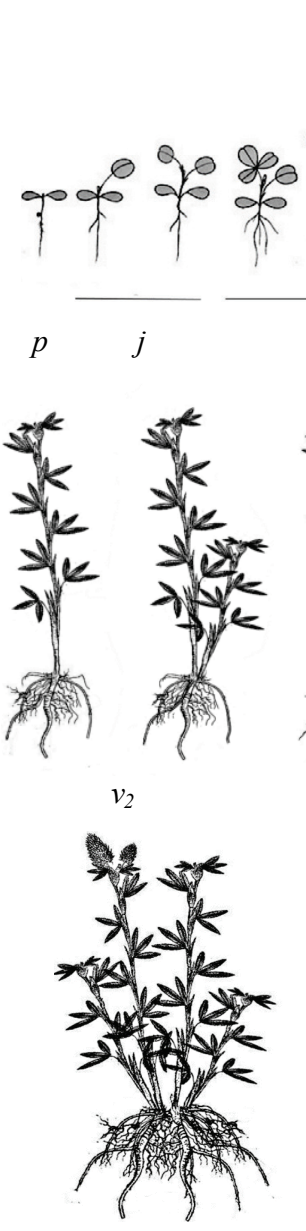

$g_{3}$

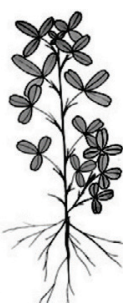

$v_{1}$
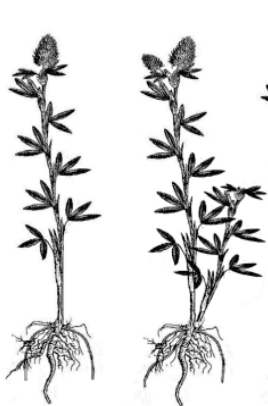

$g_{1}$

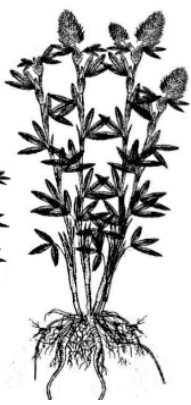

$g_{2}$
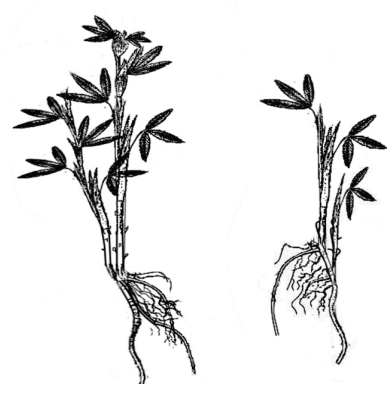

SS

$S$

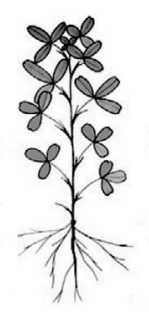

Fig. 10. Scheme of Trifolium rubens L. ontomorphogenesis stages: seedlings $(p)$, juvenile $(j)$, immature $(i m)$, virginile $(v)$, generative $(g)$, subsenile $(s s)$ and senile $(s)$

Plants form mainly 2 inflorescences on each generative shoot (Mykolaychuk, 2015), although we observed shoots with 1 or 3-6 inflorescences (due to the lateral ones) as well. Seed propagation is the main stage in the cycle of plant development.

Vegetative reproduction, which is manifested in the rooting of the lower underground parts of the shoots, is not an additional way of increasing the number of plants but provides for the prolongation of the life of individuals through additional nutrition.

The degree of development and number of shoots in generative plants reflect the state of individual and prospects of seed reproduction in the population. Establishing the real age structure of T. rubens populations in natural habitats, as in some other perennial species, is difficult. It is impossible to do this without damaging plants and soil surfaces, especially in dense communities. Such damage is unacceptable for studying rare plant species. In this case, the ratio of the number of generative and vegetative shoots may be a key for population monitoring (Kagalo et al., 2012).

\section{Conclusions}

Trifolium rubens plants go through a full cycle of development from seed formation to aging in the natural habitats and in culture condition. The 4 periods of ontogenesis in plants were observed and 11 age stages of individuals, identified and described. Plants begin flowering in the first or second year of life. The period of development from seed to generative stage takes relatively one vegetative period, and plants start flowering in the first or second year of life. Delays in the onset of the generative state are caused by poor growing conditions (lack of nutrition, moisture, or light).
The type of T. rubens development is heteroblastic. It is possible to distinguish virginile and generative individuals from subsenile and senile in shape and number of leaves on the shoots during the flowering period of plants. However, it should be borne in mind that in the phenological phase of flowering it is not possible to detect seedlings, juvenile and immature plants. Thus, data on monitoring the age structure of populations during flowering and fruiting of plants will be with incomplete age spectra (without seedlings, juvenile and imature individuals) and that will not indicate the absence of seed reproduction in the population.

In the generative period of ontogeny in dense plantings and nature, it is difficult to reliably determine the boundaries of an individual from the aboveground part. Therefore, we recommend evaluating the relationship between shoots in an individual or group of plants and use this indicator to estimate the status of a particular locus or population. The relationship between vegetative and generative shoots reflects the degree of plant development, the success of seed production, and prospects for further population development. Successful planting of T. rubens in the culture outside the natural range indicates good prospects for its ex situ protection and the implementation of measures for repatriation and restoration of populations in nature.

The publication was prepared within the research program of the M. M. Gryshko National Botanical Garden No. 387-PH "Development of scientific bases for conservation, enrichment and efficient use of resources of valuable introducers and rare plants under the influence of climate change in Ukraine" (state registration number 0117U000816) and at the authors' own expense.

The authors declared no conflict of interest.

\section{References}

Abberton, M. T. (2007). Interspecific hybridization in the genus Trifolium. Plant Breeding, 126(4), 337-342.

Bobrov, E. G. (1945). Rod Trifolium L. [Genus Trifolium L.]. In: Komarov, V. K (Ed.). Flora SSSR. Tom 11 [Flora of USSR. Volume 11]. Publishing House of the USSR Academy of Sciences, Moscow-Leningrad. Pp. 189-261 (in Russian).

Bondarchuk, O., \& Rakhmetov, D. (2016). Ontomorphogenesis of plant of the genus Astragalus L. species in conditions of introduction in the Right-Bank of ForestSteppe of Ukraine. Plant Introduction, 70, 45-51 (in Ukrainian).

Cruz-González, X., Laza-Pérez, N., Mateos, P. F., \& Rivas, R. (2017). Analysis and effect of the use of biofertilizers on Trifolium rubens L., a preferential attention species in Castile and Leon, Spain, with the aim of increasing the plants conservation status. AIMS Microbiology, 3(4), 733-746.

Didukh, J. P. (Ed.). (2009). Chervona knyga Ukrayiny. Roslynnyj svit [Red Data Book of Ukraine. Plant Kingdom]. Globalconsalting, Kyiv (in Ukrainian).

Dietz, H., \& Ullmann, I. (1998). Ecological application of 'herbchronology': Comparative stand age structure analyses of the invasive plant Bunias orientalis L. Annals of Botany, 82, 471-480.

Dudyk, N. M. (1979). Morfolohyya plodov bobotsvetnykh v svyazy s evolyutsyey [The morphology of the legumes fruits in relation to evolution]. Naukova Dumka, Kiev (in Russian).

Ellison, N., Liston, A., Steiner, J., Williams, W., \& Taylor, N. (2006). Molecular phylogenetics of the clover genus (Trifolium - Leguminosae). Molecular Phylogenetics and Evolution, 39(3), 688-705.

Gaponenko, M. B., Lebeda, A. P., Alokhin, O. O., Bahlay, K. M., Berezkina, V. I., Bilyk, O. M., Boyko, M. F., Bonyuk, Z. H., Budnyk, S. A., Buyun, L. I., Vyklyuk, M. I., Havrylenko, N. O., Havrylyuk, O. S., Haydarzhy, M. M., Halkin, S. I., Hlukhova, S. A., Hnatyuk, A. M., Derevenko, T. O., Dzyubanenko, A. S., Didenko, I. P., Dobrodziy, N. K., Zhyla, A. I., Zakharenko, H. S., Ilyenko, O. O., Kazimirova, L. P., Karabchuk, D. Y., Kozak, T. I., Kolesnichenko, O. V., Korolyuk, V. I., Kuzmishyna, I. I., Kulish, V. V., Kucherevskyi, V. V., Martynova, N. V., Menshova, V. O., Mykhaylovskyi, L. V., Moysiyenko, V. V., Nikitina, V. V., Nikiforov, O. R., Nemirchiy, A. A., Opanasenko, V. F., Orlovska, T. V., Ostapko, V. M., Ostrovska, V. A., Petrun, N. Y., Piven, I. P., Pinchuk, M. O., Pozihun, V. F., Ponomarenko, T. M., Porada, O. A., Postova, N. O., Potapchuk, L. I., Prokopiv, A. I., Repetska, H. I., Sadohurskyi, S. Y., Satiy, N. V., Semeno, O. V., Sydorenko, O. V., Smolinska, M. O., Snihur, Y. F., Soyma, D. Y., Spryahaylo, O. V., Stelmashchuk, V. H., Filatova, S. O., Khomovyi, M. M., Chubata, T. V., Shalimov, I. V., Shevchenko, L. F., \& Shol, H. N. (2011). Kataloh rarytetnyh roslyn botanichnyh sadiv i dendroparkiv Ukrajiny. Dovidkovyj posibnyk [Catalog of rare plants of botanical gardens and arboretums of Ukraine. Reference Guide]. Akademperiodyka, Kyiv (in Ukrainian). 
Gnatiuk, A. M. (2020). The growth and development of Asphodeline lutea (L.) Rchb. in a culture. Scientific Herald of Chernivtsy University, Biology, 12(1), 84-94 (in Ukrainian).

Gnatiuk, A. M., \& Gritsenko, V. V. (2019). Peculiarities of the growth and development of Paeonia tenuifolia L. on the northern border of the Forest-Steppe of Ukraine. Plant Introduction, 81, 31-43.

Gnatiuk, A., Gaponenko, M., Loya, V., \& Gaponenko, A. (2021). Distribution of Trifolium rubens in Ukraine and the current state of its populations in Zakarpattia. Plant Introduction, 89-90, 72-82.

Hiebert-Giesbrecht, M. R., Novelo-Rodríguez, C. Y., Dzib, G. R., Calvo-Irabién, L. M., G. von Arx, \& Peña-Rodríguez, L. M. (2018). Herb-chronology as a tool for determining the age of perennial forbs in tropical climates. Botany, 96(1), 73-78.

Kagalo, A. A., Tsaryk, Y. V., Skibitska, N. V., Danylyk, I. M., Sytschak, N. M., Bednarska, I. O., \& Doroshenko, K. V. (2012). Propoziciji do metodyky monitoryngu populiacij vydiv roslyn, vkliuchenyh do Chervonoji knygy Ukrajiny [Proposals to the monitoring method for populations of plant species included in the Red Data Book of Ukraine]. Proceedings of Precarpathian National University, Biology, 17, 3-8 (in Ukrainian).

Kalinkina, V. (2013). Morfo-biologicheskie osobennosti prorostkov nekotoryh vidov roda Trifolium L. [Morphological and biological features of seedlings of some Trifolium species]. Modern Phytomorphology, 3, 201-206.

Kalinkina, V. A. (2016). Stanovlenie zhiznennoj formy klevera otmennogo (Trifolium eximium Steph. ex DC. ) v ontogeneze [The formation of the life form of excellent clover (Trifolium eximium Steph. ex DC.) in ontogenesis]. Bulletin of the Moscow Society of Naturalists, Department of Biology, 121(2), 66-72 (in Russian).

Kalinkina, V. A. (2017). Onthogenetic polyvariaty in the representatives of Trifolium L. genus Lupinaster (Fabr.) Ser. section. Russian Journal of Developmental Biology, 48, 150-157.

Kolodziejek, J. (2018). Seed germination responses to some environmental factors in the red feather (Trifolium rubens). Pakistan Journal of Botany, 50(1), 59-65.

Kricsfalusy, V. (2016). Variations in the life cycle of Anemone patens L. (Ranunculaceae) in wild populations of Canada. Plants, 5, 29.

Lipinsky, V. M., Dyachuk, V. A., \& Babichenko, V. M. (Ed.). (2003). Klimat Ukrajiny [Climate of Ukraine]. Kyiv (in Ukrainian).

Marek-Kozaczuk, M., Wdowiak-Wrobel, S., Kalita, M., Chernetskyy, M., Derylo, K., Tchorzewski, M., \& Skorupska, A. (2017). Host-dependent symbiotic efficiency of Rhizobium leguminosarum bv. trifolii strains isolated from nodules of Trifolium rubens. Antonie van Leeuwenhoek International Journal of General and Molecular Microbiology, 110(12), 1729-1744.

Mikhajlova, S. I. (1998). Osobennosti ontogeneza klevera krasnovatogo v usloviyah introdukcii [Features of the ontogeny of red clover in introduction conditions]. In: Vyvchennia ontohenezu roslyn pryrodnykh ta kulturnykh flor u botanichnykh zakladakh Yevrazii. Materialy 10-ji Mizhnarodnoji naukovoji konferentsi- ji [Study of the ontogeny of plants of natural and cultural flora in botanical institutions of Eurasia. Proceedings of the 10th International Scientific Conference]. Uman. P. 107 (in Russian).

Mikolaychuk, V. G. (2012). Morfometrychni parametry listkiv generatyvnyh pagoniv roslin Trifolium rubens L. (Fabaceae) pry introdukciji v Nacionalnomu botanichnomu sadu im. M. M. Gryshka Ukrajiny [Morphometric parameters of the leaflets of generative shoots of the plants Trifolium rubens L. (Fabaceae) at introduction in the M. M. Gryshko National Botanical Garden of Ukraine. Modern Phytomorphology, 2, 165-168 (in Ukrainian).

Mikolaychuk, V. G. (2014). Osoblyvosti rostu i rozvitku roslyn Trifolium rubens L. (Fabaceae) riznyh rokiv vegetaciji u Nacionalnomu botanichnomu sadu im. M. M. Gryshka Ukrajiny [The peculiarities of the growth and development of the Trifolium rubens L. (Fabaceae) plants of different years of vegetation in the M. M. Gryshko National Botanical Garden of Ukraine]. Taurian Scientific Bulletin, 88, 133-140 (in Ukrainian).

Mikolaychuk, V. G. (2015). Morfologiya sucvit, osoblivosti cvitinnia i plodonoshennia roslyn Trifolium rubens L. (Fabaceae) riznyh rokiv vegetaciji u Nacionalnomu botanichnomu sadu im. M. M. Gryshka Ukrajiny [The morphology of inflorescences, features of flowering and fruiting of Trifolium rubens L. (Fabaceae) plants in different years of vegetation in the M. M. Gryshko National Botanical Garden of Ukraine]. Cherkasy University Bulletin: Biological Sciences Series, 335, 79-85 (in Ukrainian).

Mosyakin, S. L., \& Fedoronchuk, M. M. (1999). Vascular plants of Ukraine: A nomenclature checklist. M.G. Kholodny Institute of Botany, Kyiv.

Pavlova, N.S. (1989). Sem. Bobovyie [Fam. Fabaceae] In.: Harkevich, C. C. (Ed.). Sosudistyie rasteniya sovetskogo Dalnego Vostoka. Tom 4 [Vascular plants of the Soviet Far East. Volume 4]. Nauka, Moscow. Pp. 191-339 (in Russian).

Rabotnov, T. A. (1950). Zhiznennyj cikl mnogoletnih travjanistyh rastenij v lugovyh cenozah [The life cycle of perennial herbaceous plants in meadow cenosis]. Trudy Botanicheskogo Instituta AN SSSR, Geobotanika, 6, 179-196 (in Russian).

Smirnova, O. V., Zaugolnova, L. B., Ermakova, I. M., Bogdanova, N. M., Grigorjeva, V. N., Yegorova, V. N., Zhukova, L. A., Matveev, A. P., Mihajlova, N. F., Sugorkina, N. S., Uranov, A. A., \& Cheburaeva, A. N. (1976). Cenopopuljacii rastenij (osnovnye poniatija i struktura) [Cenopopulations of plants (basic concepts and structure)]. Nauka, Moscow (in Russian).

Visjulina, O. D. (1964). Bobovije. Trifolium rubens L. [Leguminosae. Trifolium rubens L.] In: Zerov, D. K. (Ed.). Flora URSR. Tom 6 [Flora of URSR. Vol. 6], Akademija Nauk URSR, Kyiv. P. 409 (in Ukrainian).

Yanenko, V. O., \& Litvinova, N. O. (2013). Morfologichni osoblyvosti riznyh form Trifolium rubens L. pry introdukciji [Morphological features of different forms of Trifolium rubens L. during introduction]. Scientific Bulletin "Actual Problems of Biology and Ecology”. Biological Sciences, 1, 102-104 (in Ukrainian).

Zoric, L., Merkulov, L., Lukovic, J., \& Boza, P. (2010). Comparative seed morphology of Trifolium L. species (Fabaceae). Periodicum Biologorum, 112(3), 263-272. 